Accepted: 01/07/2021, Reviewed: 23/11/2021, Published: 31/01/2022

\title{
EVALUATION OF CASSAVA CHIPS DRAINING, FINAL PRODUCT HANDLING, AND PACKAGING IN CASSAVA CHIP "OJO LALI", LAMPUNG TIMUR
}

\author{
Yuliana Sari, Wahidah Mahanani Rahayu* \\ Study Program of Food Technology, Faculty of Industrial Technology, \\ Universitas Ahmad Dahlan \\ Jl. Ahmad Yani, South Ringroad, Kragilan, Tamanan, Banguntapan, Bantul 55166 \\ ${ }^{*}$ Correspondence Author, email: wahidah.rahayu@tp.uad.ac.id
}

\begin{abstract}
Lampung is one of main cassava producer in Indonesia. One of its popular products is cassava chips, produced by many small enterprises with manual draining, product handling, and packaging. The purpose of this study was to analyze the evaluation of the handling cassava chips final product and to evaluate the packaging process of cassava chips based on package material used in Cassava Chip "Ojo Lali" East Lampung. Evaluation was conducted through direct observation on processing, packaging, and quantification of drained cooking oil. The result of this study showed that final product handling of cassava was not optimal indicated by low drained oil. Cassava chips were packed manually in polypropylene plastic by employees whom some of them were not careful, causing defect on most of the chips. Utilization of stapler to seal the packages need to be replaced for its potential hazard for consumers.
\end{abstract}

Keywords: cassava chips, final product, handling evaluation, packaging

\section{INTRODUCTION}

Cassava is one of carbohydrate source (Septiyani et al., 2012) that also contains fat, protein, fiber, vitamin B1 and C, mineral (Fe, F, Ca), and tannin (Montagnac et al., 2009). Cassava products often labeled as gluten-free, grain-free, and nut-free. Boiled cassava contains niacin (Nafilah et al., 2017). Cassava can't be consumed raw due to its hydrogen cyanide content which can be alleviated by cooking (Purwati, Thuraidah, \& Rakhmina, 2016). Cassava has been widely produced into other products such as tapioca starch and modified cassava flour and noodle, to ready-to-serve fries, gethuk, etc (Khamidah \& Krismawati, 2016). Cassava is also one of main agriculture commodities of Lampung province, with average annual productivity of 7.74 million ton during 2012-2016, that the province placed first as Indonesia cassava producer (Widaningsih, 2016). Cassava chip in balado sauce, or locally known as Chip Balado, is one of the most popular cassava product. In Lampung Timur alone, 18 cassava chips small enterprises are registered (Kusuma et al., 2020).

Some of the main challenge faced by small enterprises are quality control and final product consistency. Research on 18 cassava chips small producers in Malang reported inconsistency of frying temperature and time as well as standardized formula in each producer, hence final product inconsistency and appearance (Mustaniroh et al., 2020). Product consistency and appearance are two main attraction and identification toward consumers to buy a product. Thus, various improvement needs to be implemented in small enterprises. Moreover, most of Indonesia population is Muslim which is mandated to consume only lawful or halal and good food (thayyib), as stated in Al Quran surah 2 verse 168. In term of good food, consumers must consume product that met food safety and quality standard. Food producer must ensure that consumers only consume food that safe for consumption, free from microbial, physical, and chemical contamination. Food must be free from microbial 
contaminants, physical contaminants such as staplers pin, hair, gravel, dead insect, etc, hazardous chemicals such as cyanide that can be found in fresh cassava (Fauziah, 2020).

Quality improvement involves various important measures from processing control to final product handling, packaging, and storage. Final product handling and packaging are important as the last steps before storage or distribution and meet consumer. In term of cassava chips production, one of critical step is frying in cooking oil and draining. To prolong shelf life and hamper oxidation, cooking oil must be drained optimally and must be packed in proper packaging. Polyethylene and polypropylene and plastics are often used for food packaging, with the later has higher peroxide value than the previous when used for pinnaple chips (Chairunisa et al., 2016). In this research, final product handling and packaging in "Ojo Lali" Cassava Chip, Lampung Timur, were evaluated. The objectives were to evaluate draining as product handling result and cassava chip packaging in "Ojo Lali" Cassava Chip, one of cassava chip SMEs in Lampung Timur that is able to survive during the pandemic. The evaluation results are expected to provide information on how products are handled and provide useful input for producers of cassava chips or similar products.

\section{MATERIAL AND METHOD}

\section{Material}

Cassava chip was made using white cassava subvar IR obtained from Tambah Dadi, Purbolinggo, Lampung Timur District, Lampung Province. Other ingredients were cooking oil, red chili, garlic, sugar, salt, flavor enhancer, tamarind, lemongrass, food colorant, and citric acid obtained from traditional market.

\section{Instrument}

Several instruments were used, such as digital scale, bamboo trays for raw cassava container, and bamboo basket for oil draining.

\section{Research design}

Completely Randomized Design was applied to measure draining period as research factor on cooking oil residue attached to cassava chip and drained oil. Weighing was conducted for two days on one frying batch selected randomly for triplicate. Other data were obtained through observation and interview with owner and worker.

\section{Research stages}

Data was collected through several methods. First, through interview conducted with owner and 20 workers in production and packaging unit. Second, through direct observation. Direct observation was conducted by weighing of cassava chip before and after frying, cooking oil after draining, and documentation of packaging process. Pictures were taken according to observation relevance with owner permission.

\section{Method}

This study was conducted using observation. Direct observation was done on the site of production to record the description of cassava processing into chips, as well as cassava chips weighing during various processing stages. The description and other information were also collected by interview with workers and the owner. During observation, pictures were taken, especially during packaging, to record the form of package and product label.

\section{Analysis Procedure}

Further analysis was conducted to determine problems and how they emerge based on collected data then was represented in fishbone diagram. Weighing was conducted in several stages below to measure draining efficiency through the amount of dripping oil.
a. Raw thin slices cassava before frying
b. Cassava chip right after frying with attached oil
c. Dripping oil before draining 
d. Cassava chip after draining for 5 and 10 minutes

e. Dripping oil after draining

Data from interview, observation, and weighing were analyzed and presented in tables and fishbone diagram. All photos presented in this article are personal documentation.

\section{RESULT AND DISCUSSION}

\section{Evaluation of Final Product Handling}

Appearance is the first attraction for consumer to by food product. Evaluation on product handling must be conducted to ensure quality stability, for short or long-term, especially for product which processed by frying (Rustianasari, 2020). Evaluation on processing might also help small enterprises to determine challenges and problems currently being faced, as well as weakness and strength for sustainable product improvement.

In Cassava Chip "Ojo Lali”, cassava was fried, drained, mixed with thick Balado sauce, and packed before storage and distribution. Cassava chip frying was manually done by pouring thinly sliced cassava into hot cooking oil, stirring for few minutes until chips become slightly brown, then lifted and drained. However, after frying all batch of cassava, the leftover oil is kept in frying pan to be used for the following day with addition of fresh cooking oil, that the oil become repeatedly used. This practice contains potential chemical hazard on consumer's health. Frying in high temperature generates free fatty acid, carbonyl compounds, and peroxide which can cause chronic poisoning in humans (Hidayati, Masturi, \& Yulianti, 2016). Fried cassava was then manually drained and let sit in bamboo basket that put on big bucket to collect dripping oil from draining Figure 1 and 2.

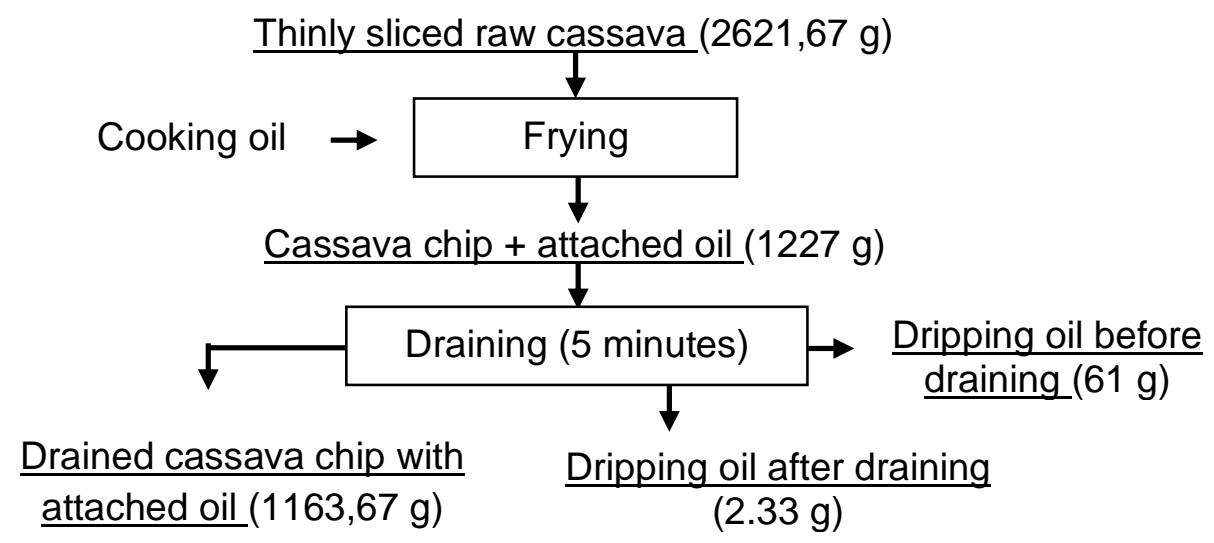

Figure 1. Diagram of oil and cassava weighing at day-1 (5 minutes draining)

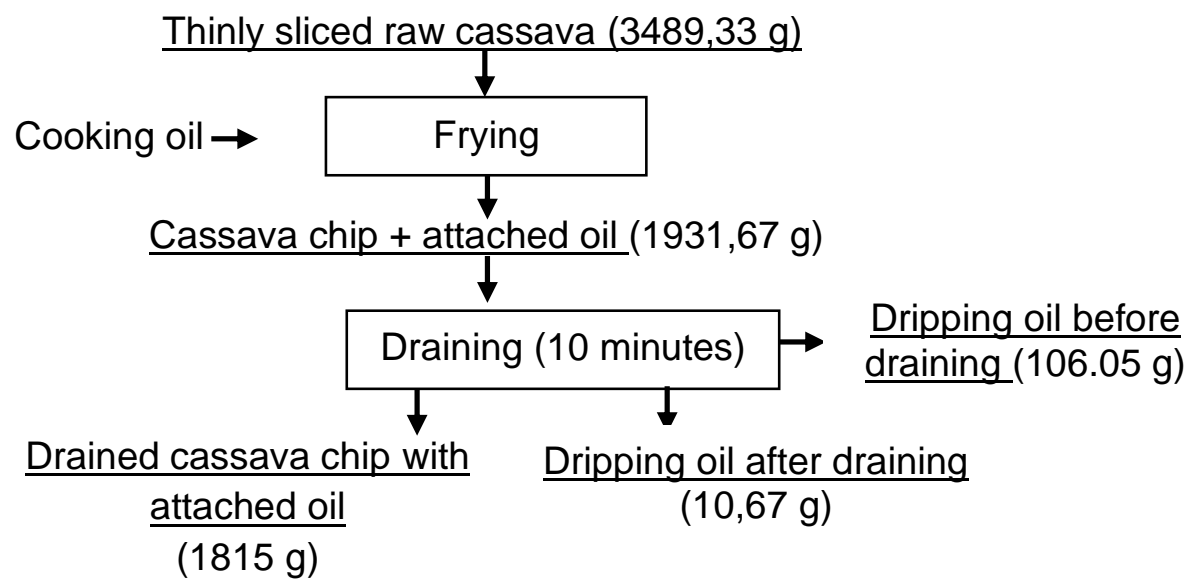

Figure 1. Diagram of oil and cassava weighing at day-2 (10 minutes draining) 
Weighing was conducted on thinly sliced raw cassava before frying, fried cassava chip right after frying, dripping oil just before draining and after draining, as well as cassava chip after draining. Then percentage of total dripping oil was calculated in comparison to fried cassava with attached oil to measure the difference percentage of dripping oil at different draining period Table 1.

Based on data, dripping oil amount was comparable to fried cassava chip weight. Draining in "Ojo Lali" is done manually by placing chips in bamboo basket, hence low efficiency and effectivity. The surface of cassava chip was oily even after draining. This inefficiency might consume a lot of oil. Dripping oil should be able to be optimally removed by draining. Weighing diagram below Figure 1 and 2 aimed to better explain the effect of different draining period in day-1 and day-2. There was difference in drained oil due to the difference of cassava weight and draining period. Draining was conducted for 5 minutes like how it usually done in "Ojo Lali", and added to 10 minutes to measure any difference result for prolonged time. In longer draining period, the amount of oil increased. Therefore, draining result was affected by the amount cassava and draining period. However, there was only slight increase in draining result shown by percentage of total dripping oil compare to fried cassava + attached oil. The result indicated that 5 minutes difference was too short and only resulted slight increase on dripping oil.

Table 1. Weight of several cassava chips and oil in different processing stages

\begin{tabular}{lcc}
\hline \multicolumn{1}{c}{ Material } & \multicolumn{2}{c}{ Weight (g) } \\
\cline { 2 - 3 } & $\mathbf{5}$ minutes draining & $\mathbf{1 0}$ minutes draining \\
\hline Raw cassava chip & $2621.67 \pm 2.51$ & $3489.33 \pm 4.32$ \\
Fried cassava chip + attached oil & $1227.00 \pm 3.01$ & $1931.67 \pm 5.19$ \\
Cassava chip after draining & $1163.67 \pm 1.21$ & $1815.04 \pm 1.24$ \\
Dripping oil just before draining & $61.00 \pm 0.50$ & $106.05 \pm 2.98$ \\
Dripping oil after draining & $2.33 \pm 0.12$ & $10.67 \pm 0.11$ \\
\hline Percentage of total dripping oil & & $6.04 \%$ \\
compare to fried cassava + & $5.16 \%$ & \\
attached oil & &
\end{tabular}

Number was mean \pm standard deviation of triplicate weighing

After draining, cassava chip is usually mixed with thick hot sweet sauce known as Balado sauce, thus sauce-mixed cassava chip is the final product before packaging and distribution. Based on quality requirement of SNI 01-4305-1996, Cassava Chip "Ojo Lali" meet sensory standard of normal aroma, normal taste from hot sweet sauce, normal chip color, and crispy. However, generally observed visually, only $80 \%$ intact chip can be found in each package that not eligible to standard of $90 \%$. Cassava Chip "Ojo Lali" also use dark red food colorant at $5 \mathrm{ml} / \mathrm{L}$ in hot sweet sauce that meet the standar by Indonesia food and drug administration BPOM 11/2019 on Food Additives below $500 \mathrm{mg} / \mathrm{kg}$. Citric acid addition also meet the standard of $60 \mathrm{~g} / 15 \mathrm{~kg}$ sugar.

Other than draining, cassava chip form must be improved. Most cassava chip in a package was crushed, but all chips in any condition were packed. Moreover, as the factory consider irregular form has no significant impact on selling rate, packaging was done by workers carelessly, even break the chips to make them easier to put into package. This condition must be improved as many consumers consider the appearance and package design as consideration before buying cassava chips (Aini, Syafi'i, \& Kuntadi, 2014; Yulia, 2018). Consumer's perception might be thinking that the product has been long stored in shops from its damaged form and negatively impact their buying. Such condition can be caused by several factors that must be improved, such as equipments, workers, and method, as presented in fishbone diagram below Figure 3 . 
Causative factor for low volume of drained oil in "Ojo Lali" was analyzed below.

1. Worker

There was lack of awareness among workers to improve draining process to remove most cooking oil off of chips. Workers did not pound the bamboo basket containing chips during draining. Therefore, oil on cassava chip surface cannot maximally drained. A large part of oil was still attached on chips' surface. There was also no effort to maximize draining process from lack of workers knowledge.

2. Equipment

Draining was conducted manually using bamboo basket. Chips were only left to let sit in big bamboo basket for few minutes, that the draining become less effective.

3. Method

There were two aspects in the method that affected draining, the period and implementation

of standard operational procedure (SOP). Draining period was only 5 minutes for each frying batch due to the limited number of bamboo basket used for draining. To prevent bottle neck after frying, workers tend to use the basket for very short time. The second was improper implementation procedure. The procedures were passed from the head or supervisor of production to old and new workers, such as workers should pound the basket during draining and to avoid excessive amount of chips drained in each basket. Workers tend to use each bamboo basket for as many chips as possible without pounding without any reprimand, thus cooking oil remained attached to the chips.

thus cooking oil remained attached to the chips.

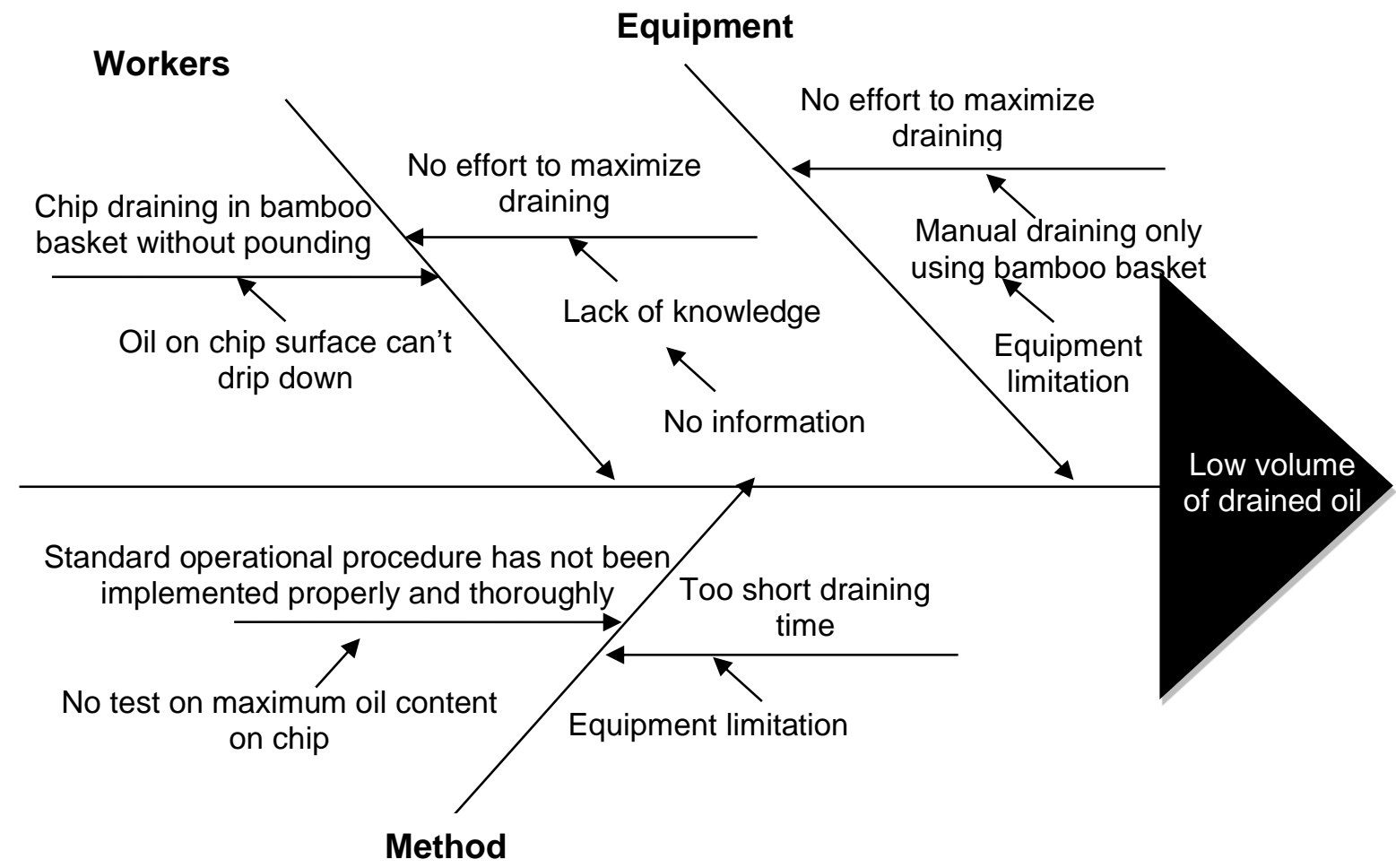

Figure 3. Fishbone diagram on several factor causing low volume of drained oil

\section{Cassava Chip Packaging}

As previously mentioned, package of cassava chips that used as wrapper might also plays important role to sell the product. In cassava chips, packaging is one of the decisive factor to buy the product (Aini, Syafi'i, \& Kuntadi, 2014). Package is the container of the product which constitutes of the combination of form, including color, design, label, and material (Agariya et al., 2012). According to World Trade Organization, packaging is an integrated system that must be effective, efficient, and easy to preserve, protect, and prepare the product during transportation and distribution to consumer. Its main purpose is to preserve 
and prepare product quality so that the consumer might consume the best and safest product. In term of selling, package form, color, and design should also become some sort of marketing tools as well as decisive point for consumer to buy the product. Moreover, proper label should also put on the package, including nutritional fact, ingredients, authorization prove, and all aspect that mandated by regulations (Irrubai, 2015). Article 82 paragraph (1) of Law Number $18 / 2012$ on Food states that everyone who produces packaged food is obliged to use food packaging materials that do not endanger human health or caused contamination that endangers human health. Proper package might protect the product against bump, physical shock, and damage caused by physical, chemical or microbiological substances during distribution and storage.
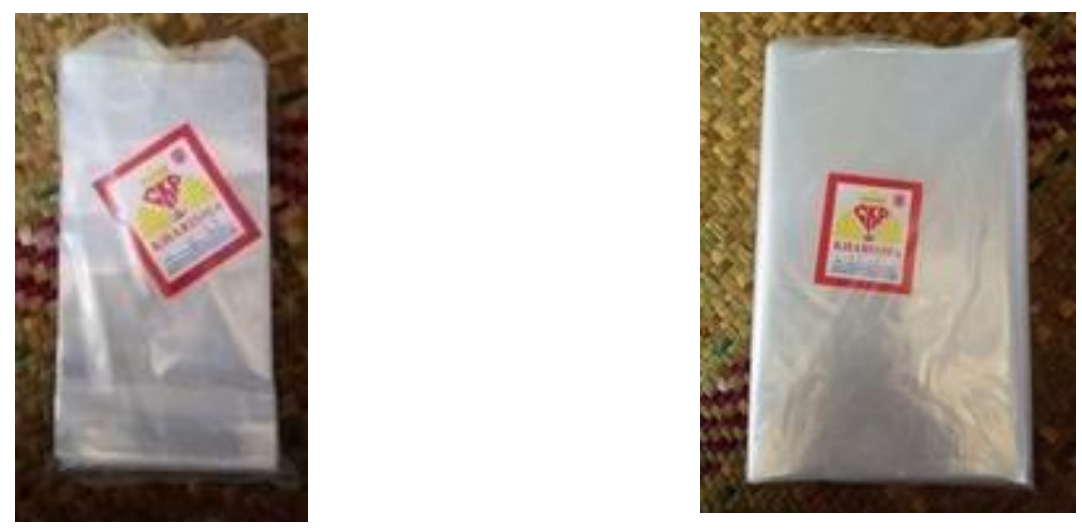

Figure 4. Small $(9 \times 17 \mathrm{~cm})$ and big package $(23 \times 40 \mathrm{~cm})$ in Cassava Chip "Ojo Lali"

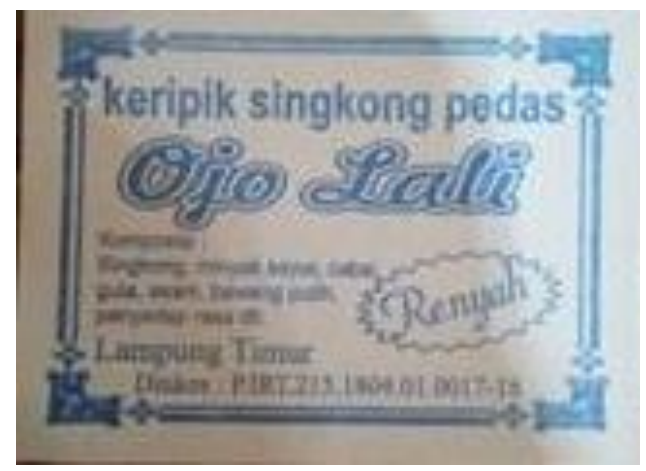

Figure 5. Label of Cassava Chip "Ojo Lali"
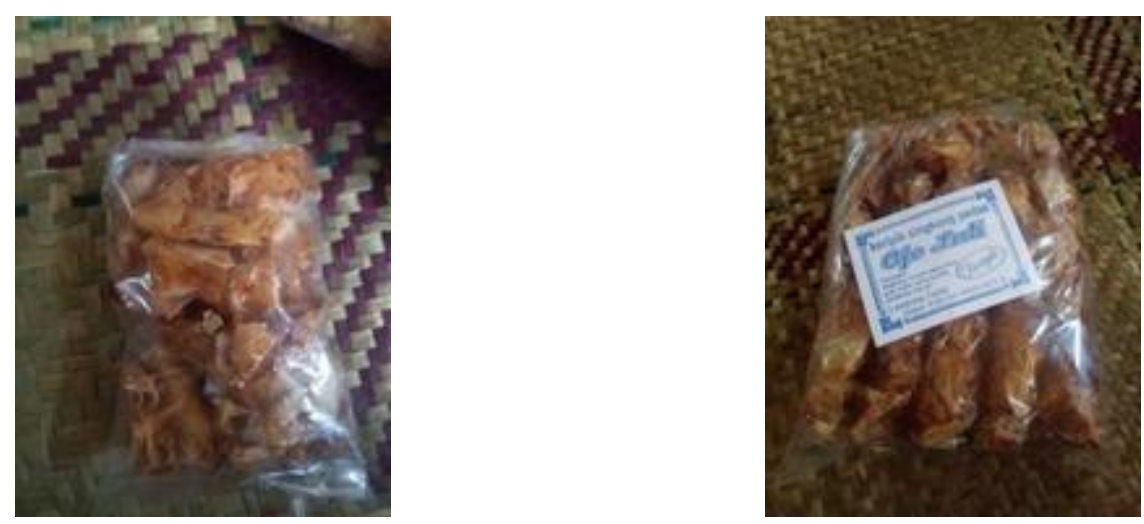

Figure 6. Cassava Chip "Ojo Lali" in small package of 45-50 g and big package

Cassava Chip "Ojo Lali" uses plastic package of $0.3 \mathrm{~mm}$ polypropylene (PP) for years due to its integrity, durability, practical use, with reasonable price. Chips are packed in two size of $9 \times 17 \mathrm{~cm}$ small pack and $23 \times 40 \mathrm{~cm}$ big pack filled with 12 small packages. Therefore, 
small package served as primary package, while the big one as secondary. Though many chips brand use polyprophylene plastic for its ability to prevent sluggish, but it can not prevent rancidity, thus Guidelines for Selection of Food Package released by Indonesia FDA BPOM number 16/2014 recommend PET12 /CPP25 laminated package. The package should prevent contamination, as well as photooxidation in particular, as cassava chips is fried and contain cooking oil. It was reported that frying of cassava chips reduced oxidation stability, thus increase the potential of oxidation (Corsini, Silva, \& Jorge, 2009). Oxidation become more prone due to utilization of plastic packaging.

In Cassava Chip "Ojo Lali”, packaging was still handled manually. Cooled cassava chip previously mixed with hot sweet sauce was put into small plastic package that sealed using staplers, 45-50 gram each. Small packages then packed into bigger plastic before labeling and room temperature storage. Utilization of staplers in food products packaging has physical hazard and risk to consumer health and safety, therefore it has been discouraged by food safety agencies around the world.

Simple paper label was used in Cassava Chip "Ojo Lali". Regulation of the head of BPOM number $31 / 2018$ on Processed Food Labels states that all food products must provide correct and clear information to consumer on product profile. Label must provide product name or brand, ingredient and composition including food additives, netto, name and address of producer or importer, certification of halal or other marketing authorization, production date and code, expired date, and origin of certain foodstuffs. Label of Cassava Chip "Ojo Lali" only has product name or brand, general ingredient, address, and food processing permit number (P.IRT.215.1804.01.0017-18), which was ineligible to the regulation. The label provided no information on production date, expired date, and netto, while the product has no halal certificate. From interview with the owner, during P.IRT certification, the company only receive basic training on food safety and hygiene, but has not receive any training on labelling or shelf life forecasting from government agency.

Cassava Chip "Ojo Lali" that are no longer fit for consumption will look very oily at the bottom of the package with rancid smell, approximately 3-4 months from after production. Products in stores and shops with these marks will be returned to "Ojo Lali". Product will be shared among workers if still edible, or thrown away or given to cattle if inedible. Returned product had always been a few that considered impactless. Based on observation on packing process in Cassava Chip "Ojo Lali", there were several factors that need to be improved, as presented in fishbone diagram (Figure 7).

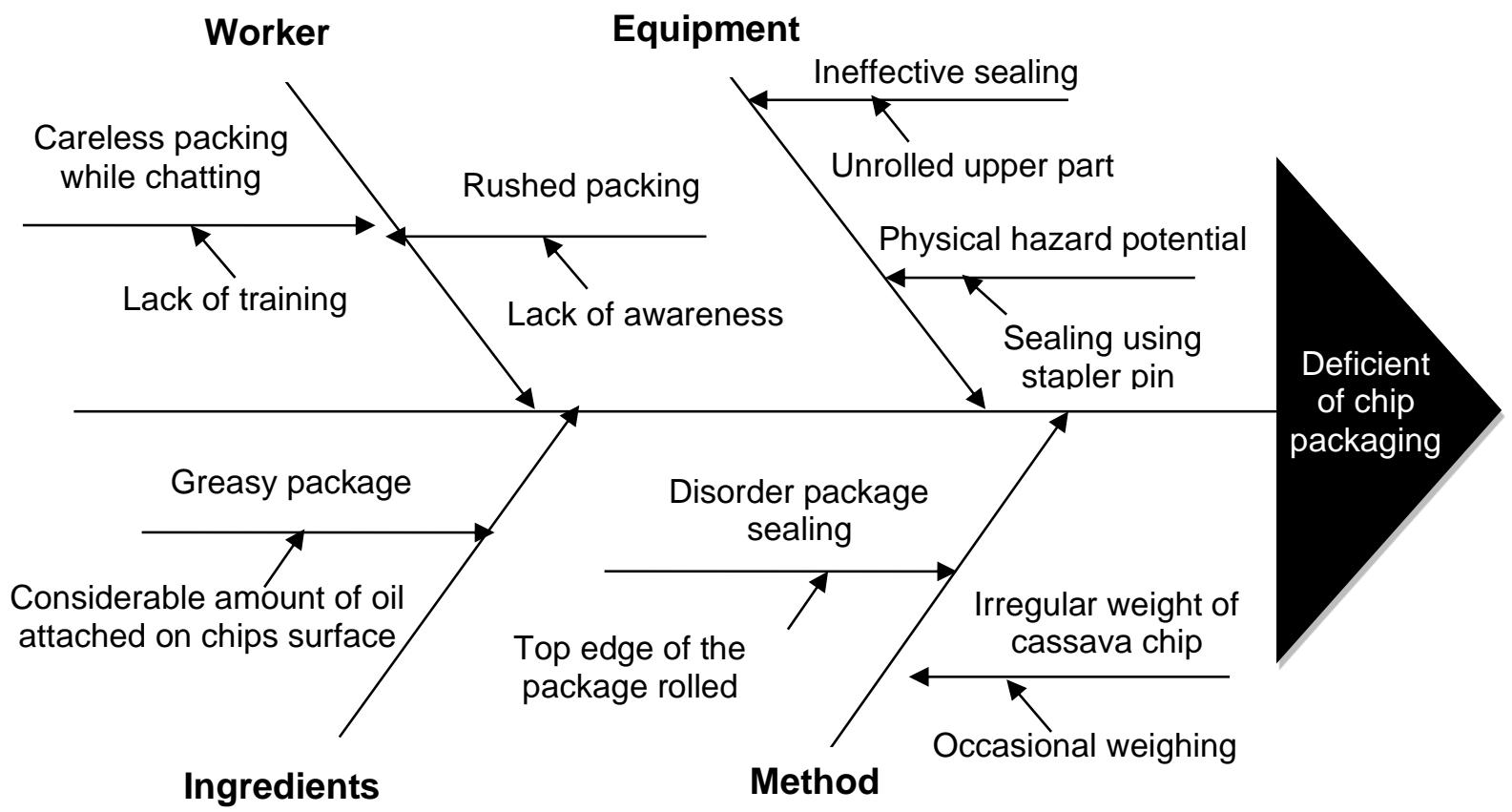

Figure 7. Fishbone diagram on factors related to deficient of chip packaging 
1. Worker

Several factors that need to be improved were as follows.

Cassava chip was packed by workers carelessly while chatting among them and lack attention on packed product. Packing was also done in rush to finish more chips and gain more wages. A large part of cassava chip became disintegrated after packing due to worker's carelessness when inserting the cassava chip into the package. Workers must be trained to give bigger awareness on how to maintain product quality and to be more careful during packing.

2. Equipments

Packages were sealed using staplers pin, some of which still easily opened. Stapler's pin must be replaced with other safer equipments, such as electrical heat sealer, to reduce physical hazard potential for consumer.

3. Method

Weight consistency was not controlled due to lack of product weighing. Weighing was only done occasionaly, even only 1-2 times a day, and not on all chip packages, caused irregularity of each cassava chip package weight. Some packages were also had upper part unrolled as they were folded carelessly.

4. Material

Due to the short draining time, a considerable amount of oil was still attached on chip that the package became greasy. The oil that sticks to the hands of worker was occasionally transferred on the surface of package that rarely cleaned by workers.

As far as the authors know, there was no research or observation to forecast the shelf life of "Ojo Lali" products. There was also no record on when should the chips be returned to producer due to off flavor or any other defect. Therefore, several suggestions were proposed for Cassava Chip "Ojo Lali" improvement:

1) They must provide person in charge for raw material selection and quality control to ensure good cassava is selected while maintaining product quality based on standard.

2) Utilization of spinner drainer to reduce oil on cassava chip.

3) Regularly provide training for workers, particularly in packaging section to raise awareness on its important toward product quality and on how to maintain chip form.

4) Improve labeling with production date and estimated shelf-life or expiry date.

5) Application of heat sealer to seal plastic package to reduce potential of physical hazard.

6) Daily replacement with fresh cooking oil to prevent chemical hazard potential on consumer. Old cooking oil can be sent to biodiesel production unit.

7) To build collaboration with institutions that can conduct research to assess cassava chips shelf life

\section{CONCLUSION}

In Cassava Chip "Ojo Lali", final product of cassava chip was handled rather in suboptimal condition, particularly in draining and packaging. A significant amount of product was greasy, while packaging was done manually using polyprophylen plastic and rather carelessly, hence damaged product form and irregularity. Stapler pins were also used to seal package. Several improvements need to be done to increase product quality, from raw material selection, quality control, worker training, cooking oil daily replacement, utilization of spinner for draining, and heat sealer for packaging.

\section{REFERENCES}

Agariya, A. K., Johari, A., Sharma, H. K., Chandraul, U. N., \& Singh, D. (2012). The Role of Packaging in Brand Communication. International Journal of Scientific \& Engineering Research, 3(2), 1-13. 
Aini, S. N., Syafi'i, I., \& Kuntadi, E. B. (2014). Consumer Behavior for Purchasing Salty Cassava Chips in Bondowoso. Berkala IImiah PERTANIAN, 1-8.

Chairunisa, Asih, E. R., \& Restusari, L. (2016). The effect of pinapple chips storage in various packages on shelf life using Accelerated Shelf-Life Testing (ASLT). Riau: Poltekkes Kemenkes Riau. doi:https://doi.org/10.31227/osf.io/byxg2

Corsini, M. S., Silva, M. G., \& Jorge, N. (2009). Loss in tocopherols and oxidative stability during the frying of frozen cassava chips. Grasas y Aceites, 60(1), 77-81.

Fauziah, A. N. (2020). Cyanide content of cassava (Manihot esculenta) on various processing method. Tasikmalaya: STIKes BAKTI TUNAS HUSADA.

Hidayati, F. C., Masturi, \& Yulianti, I. (2016). Purification of used cooking oil using corn cob charcoal . Jurnal IImu Pendidikan Fisika, 1(2), 67-70.

Irrubai, M. L. (2015). Strategy of labelling, packaging, and marketing for home industry products in Monjok Village, Selaparang District, Mataram City, Nusa Tenggara Barat. Society, Jurnal Jurusan Pendidikan IPS Ekonomi, XIII, 15-30.

Khamidah, A., \& Krismawati, A. (2016). Consumer Preference of Products from Purple Sweet dan Cassava in Madiun Regency, Jawa Timur Province. Jurnal Pengkajian dan Pengembangan Teknologi Pertanian, 19(2), 135-151.

Kusuma, E. W., Widjaya, S., \& Situmorang, S. (2020). Analysis of Raw Materials Procurement and Value Added of Cassava Chips in Way Jepara District, East Lampung Regency. JIIA, 8, 70-77.

Montagnac, J. A., Davis, C. R., \& Tanumihardjo, S. A. (2009). Nutritional Value of Cassava for Use as a Staple Food and Recent Advances for Improvement. Comprehensive Reviews in Food Science and Food Safety, 8(3), 181-194.

Mustaniroh, S. A., Tarigan, I. F., \& Maligan, J. M. (2020). Improving the Quality of Production Process in Cassava Chips UKM, Malang Regency. Jurnal Pangan and Agroindustri, 8(1), 13-18.

Nafilah, Asyiah, I. N., \& Fikri, K. (2017). Ethnobotany Study of Pharmaco-potency of Cassava Plant in Bondowoso Regency. Jurnal Saintifika, 19(2), 43-54.

Purwati, Y., Thuraidah, A., \& Rakhmina, D. (2016). Cyanide levels of boiled cassava and fried cassava. Medical Laboratory Technology Journal, 2(2), 46-50.

Rustianasari, T. (2020). The Concept of Good Manufacturing Practices (CPPB) in Menjes Tempe Chips Production at "DRT Kripik" in Ngrambe District, Ngawi Regency, Jawa Timur Province. Surakarta: Universitas Sebelas Maret.

Septiyani, Effendi, I. R., \& Hartati, Y. (2012). Glycemic Index of Various Tiwul Food Products Based on Cassava (Manihot esculenta Crantz) in Normal People. Bogor: IPB University.

Widaningsih, R. (2016). Outlook on Agricultural Commodities Subsector Food Plants: Cassava. Jakarta: Kementerian Pertanian.

Yulia, E. (2018). Analysis of Factors Affecting Consumers in Purchasing Cassava Chips. Jurnal EKBIS, XIX(1), 1100-1120. 